\title{
PERAN KESENIAN REYOG KENDHANG SANGTAKASTA SEBAGAI SARANA BEREKSPRESI MASYARAKAT DESA TUGU KECAMATAN SENDANG KABUPATEN TULUNGAGUNG
}

\author{
Mayendra Rifai Yahya \\ Program Studi Pengkajian Seni Musik \\ Pascasarjana Institut Seni Indonesia Yogyakarta \\ e-mail : mayendra66@gmail.com
}

Diterima : 17 Maret 2019. Disetujui : 9 Mei 2019. Dipublikasikan : 30 Juni 2019

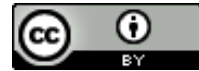

(C2019 - DESKOVI Universitas Maarif Hasyim Latif. Ini adalah artikel dengan akses terbuka di bawah lisensi CC BY 4.0 (https://creativecommons.org/licenses/by/4.0/)

\begin{abstract}
ABSTRAK
Keberadaan Sangtakasta memiliki daya tarik tersendiri untuk dijadikan sebagai objek penelitian. Keseniankesenian tradisional dihadapkan dengan modernitas kemajuan zaman di era globalisasi yang serba canggih ini. Perubahan kebudayaan suatu daerah sedikit banyak dipengaruhi oleh perubahan-perubahan masyarakatnya. Kesenian-kesenian tradisional dengan konsep-konsep lama semakin sulit mencari peminat, setelah para generasi mudanya kurang tertarik karena tidak adanya suatu pembaharuan. Anak-anak muda lebih cenderung menyukai bentuk kesenian yang kekinian atau masa kini. Munculnya grup-grup kesenian di Kabupaten Tulungagung dengan kreativitasnya masing-masing, sedikit banyak memberi angin segar terhadap pelestarian kearifan lokal daerah. Kesenian tradisional seperti Reyog Kendhang tak luput dari objek ajang berkreativitas dalam berkesenian. Sangtakasta sebagai sanggar seni yang berada di Desa Tugu Kabupaten Tulungagung ini, saat ini sangat berperan penting dalam hal memfasilitasi minat dan bakat anak-anak muda yang ingin terjun langsung dalam berkesenian. Konsep garapan baik tarian atau musikal, semuanya disesuaikan dengan perkembangan zaman atau tren masa kini tanpa meninggalkan dasar-dasar dari kesenian itu sendiri. Kesenian tanpa adanya sebuah pembaharuan mustahil akan tetap eksis melintasi generasi ke generasi, sebab sebuah kesenian akan selalu berkembang sesuai dengan perubahan zaman. Reyog Kendhang sebagai kesenian ikon dari Kabupaten Tulungagung saat ini juga tidak luput dari sebuah pembaharuan, karena kearifan lokal akan hilang tanpa adanya masyarakat pendukung. Pendekatan etnomusikologi,sosiologi dan antropologi digunakan sebagai sarana untuk memperoleh informasi yang lebih efisien dengan metode deskriptif analisis. Hasil daripada penelitian ini bahwasanya sebuah kesenian akan terus berkembang sesuai dengan perubahan zaman, mengikuti alur perkembangan zaman sah-sah saja asalkan tidak meninggalkan dasar dari kesenian itu sendiri. Musik Reyog Kendhang Sangtakasta saat ini mampu menyesuaikan zaman sesuai dengan minat masyarakat pendukungnya.
\end{abstract}

Kata kunci: Seni, Reyog Kendhang, Sangtakasta

\begin{abstract}
Sangtakasta's existence has its own attraction to be used as the object of research. Traditional arts are confronted with modernization in globalization era. Changes of the culture in region are influenced by changes of society. Traditional arts with old concepts are difficult to find enthusiasts, after young people generation is less interested because there is no update in traditional art. Young people prefer contemporary art forms. The emergence of art groups in Tulungagung Regency with their respective creativity, gave a fresh update to the preservation of the local wisdom of the region. Traditional arts such as Reyog Kendhang is always as an objects of creativity in the arts. Sangtakasta as an art studio located in Tulungagung Regency Tugu Village currently plays an important role in facilitating young people's talent who want to get involved in art. The project of sangtakasta studio is dance and musical, all adapted to the current trends without leaving the basics of the art itself. Art without update is can't exist across generations, because an art will always develop in accordance with changing times. Reyog Kendhang as an iconic art from Tulungagung Regency is currently has an update, because local wisdom will be lost without the support community. Ethnomusicology, sociology and anthropology approaches are used to obtain more efficient information with descriptive analysis methods. The results of this study that an art will continue to develop in accordance with the changing times, follow the flow of the development of the times is fine as long as it does not leave the basis of art itself. Reyog Kendhang Sangtakasta Music is currently able to adjust the times according to the interests of the supporting community
\end{abstract}

Keyword: Arts, Reyog Kendhang, Sangtakasta 


\section{PENDAHULUAN}

Istilah Reyog Kendhang jika ditinjau dari pengertian masyarakat di daerah Kabupaten Tulungagung kemungkinan besar akan menunjukkan sebuah jenis pertunjukan tari yang menggunakan kendhang gembluk sebagai properti yang sekaligus instrumen pokoknya. Hal tersebut tidak jauh berbeda dengan pertunjukan yang menggunakan properti kudakudaan berbahan anyaman bambu maupun kulit disebut dengan istilah jaranan. Pada kenyataanya memang banyak sekali istilah-istilah untuk menyebut kesenian atau pertunjukan yang memakai properti dan dijadikan nama dari kesenian tersebut. Akhir-akhir ini pemerintah telah mengambil kebijakan untuk merevitalisasi kesenian tradisional yang hampir punah. Usaha penggalian kembali ini untuk mencapai sasaran program pemerintah dalam rangka pembangunan guna melestarikan tradisi kesenian yang telah tumbuh dan berkembang sebagai hasil budaya bangsa. Soedarsono berpendapat bahwa istilah jathilan, kuda kepang, dan reyog memang merupakan nama yang lazim digunakan untuk menyebut jenis pertunjukan itu. Kata reyog berasal dari kata rog, rog sama dengan reg dan yog. Rog bisa berarti erog, herog, rog-rog asem. Reg bisa berarti horeg, reg-regan, dan yok menjadi hoyok, oyok. Kesemuanya itu mengandung arti yang sama yaitu bergerak atau berguncang. Berangkat dari pengertian di atas, arti kata reyog dapat dikategorikan ke dalam satu arti yang sama yaitu merupakan tarian kelompok yang berbentuk arak-arakan (prosesi). Reyog Kendhang merupakan kesenian tradisional dari Kabupaten Tulungagung yang berbeda dengan reyog lainnya.

Reyog Kendhang lebih cenderung pada sekumpulan penari yang memainkan alat musik kendhang gembluk dan di padukan dengan kesenian jaranan, tetapi yang menjadi pembeda kesenian ini dengan reyog-reyog yang lain tidak ada properti kudakudaan dalam pertunjukannya. Pemain akan fokus memainkan gembluk sebagai instrumen utama dalam pertunjukannya yang mengatur tempo dan pola ritmis pada gerakan tarian. Gembluk adalah alat musik yang berbentuk kendhang pada sisi depan saja yang diberi penutup kulit. Kulit yang sering digunakan adalah kulit kambing dan sapi, sedangkan bagian belakang tetap berlubang atau bermemban satu.. Gembluk dikatakan sebagai kendhang karena berfungsi sebagai pamorba irama selayaknya kendhang bermembran dua.

Masyarakat dalam proses kehidupannya pasti akan mengalami perubahan. Perubahan sosial di dalam suatu masyarakat juga akan diikuti oleh perubahan budaya, hal ini dikarenakan masyarakat tidak bisa terlepas dari kebudayaannya. Begitu juga dengan kesenian Reyog Kendhang Tulungagung yang mengalami perubahan dari masa ke masa, baik dari segi musikal berupa pola permainan, penyajian, maupun dari segi fungsinya.

Dahulu musik Reyog Kendhang cenderung monoton dan minim kreativitas, tetapi seiring berkembangnya zaman musik Reyog Kendhang semakin banyak mengalami perubahan. Reyog Kendhang yang dulunya sebagai sarana ritual, sekarang juga digunakan sebagai sarana hiburan, sarana komunikasi, media ekspresi, media komersial untuk mencari nafkah dan lain sebagainya. Hal ini bisa dilihat pada grup Sangtakasta pimpinan Endin Didik Handoko yang berada di Desa Tugu Kecamatan Sendang Kabupaten Tulungagung. Rumah Budaya Sangtakasta hampir setiap malam dipenuhi oleh banyak masyarakat baik dari kalangan orang tua, anak-anak dan mudamudi untuk bermain Reyog Kendhang.

Hal ini cukup menarik karena masyarakat di Desa Tugu mayoritas adalah petani, setiap pagi mereka menghabiskan waktu untuk pergi ke sawah maupun ke ladang. Kegiatan berkesenian biasanya dilakukan saat malam hari hingga larut malam, karena hanya malam hari semua masyarakat bisa bersantai-santai dan berkumpul bersama. Bisa jadi kegiatan berkesenian tersebut sebagai pelepas lelah ataupun wadah untuk menyalurkan bakat dalam berkesenian.

Konsep penggarapan disesuaikan dengan zaman tanpa meninggalkan pola bakunya. Seni tradisi dihadapkan secara diametral dengan perubahan yang pesat di segala sektor, itulah yang secara sederhana disebut modern. Tradisi dan modern menjadi dua kutub yang bisa saling mengisi dan saling tarik menarik sehingga muncul warna baru, walaupun di satu sisi masih ada yang mempersoalkan efektifitas dan efisiensi. Kreativitas anak-anak muda Desa Tugu bisa dilihat dari penggarapan musiknya, mereka berani melepaskan pola baku permainan Reyog Kendhang yang biasanya menggunakan pola ketukan 4/4 menjadi 3/4. Pada pemilihan instrumen mereka menambahkan instrumen musik barat seperti seperangkat drum, simbal dan tamborin untuk membuat musik yang lebih kekinian sesuai jiwa muda dan menambahkan beberapa demung dan saron sesuai konsep materi yang dibuat.

Kenyataan di lapangan kesenian ini disukai oleh masyarakat dan kaum muda. Begitu juga dengan pemain musiknya, seolah-olah kepercayaan dirinya meningkat. Eksistensi Reyog Kendhang di era masyarakat modern tidak lepas dari kesadaran dan peran masyarakat yang peduli akan seni dan budaya bangsanya. Munculnya kelompok-kelompok masyarakat yang peduli terhadap kesenian Reyog Kendhang secara tidak langsung memberi dampak positif terhadap pelestarian warisan budaya tersebut. Inovasi yang muncul dalam musik Reyog Kendhang seperti penggunaan sistem perubahan birama, motifmotif pukulan nadanya dan bentuk penyajian musiknya membuat kesenian ini lebih komunikatif dan bervariasi dalam perkembangannya, walaupun demikian masyarakat setempat tidak melupakan pola-pola bakunya baik dari segi musikal dan gerak tariannya, sehingga Reyog Kendang Tulungagung masih tetap bertahan di era modern ini. Inovasi terhadap musik Reyog Kendhang ini memberikan dampak positif bagi 
upaya pelestarian seni dan budaya di Tulungagung khususnya dan Indonesia pada umumnya.

\section{PEMBAHASAN}

\section{Bentuk, peran dan fungsi kesenian reyog kendhang sangtakasta kabupaten tulungagung}

Kesenian Reyog Kendhang cukup banyak diminati oleh masyarakat Tulungagung khususnya di Desa Tugu Kecamatan Sendang Kabupaten Tulungagung. Hampir disetiap pelaksanaan acara-acara selalu menampilkan kesenian ini, seperti perayaan Hari Jadi Kota, pernikahan, khitanan, ngruwat bayi, kampanye partai politik, upacara-upacara tahunan seperti jamasan tombak Kyai Upas dan lain sebagainya. Di Desa Tugu Sendiri, kesenian sudah menjadi satu dengan kehidupan masyarakatnya. Berkesenian merupakan kegiataan yang rutin dijalankan untuk melepas penat setelah seharian bekerja.

Masyarakat di Desa Tugu mayoritas adalah petani dan peternak, desa yang terletak di bawah kaki Gunung Wilis ini sangat mendukung untuk kegiatan pertanian seperti menanam kobis, teh dan tumbuhtumbuhan lainnya yang hidup subur di dataran tingggi. Kegiatan berkesenian biasanya dilakukan malam hari untuk melepas penat. Seni selain sebagai alat untuk melepas lelah setelah bekerja juga digunakan untuk ajang silaturahmi antara masyarakat satu dengan lainya. Sehingga tenggang rasa masyarakat di Desa Tugu sangat erat, bagaimana seni bisa digunakan untuk belajar saling memahami dan menciptakan kerukunan antar sesama.

Menurut Koentjaraningrat, kebudayaan adalah sistem gagasan, tindakan, dan hasil karya manusia dalam rangka kehidupan masyarakat yang dijadikan manusia dengan belajar. Dalam kehidupan masyarakat, kesenian ternyata merupakan perpaduan dari tiga wujud kebudayaan seperti yang diungkapkan oleh Koentjaraningrat, yaitu :

1. Wujud kebudayaan sebagai suatu kompleks dari ide-ide, nilai-nilai, norma,serta peraturan.

2. Wujud kebudayaan sebagai suatu kompleks efektifitas tindakan berpola dari manusia dalam masyarakat.

3. Wujud kebudayaan sebagai benda-benda hasil karya manusia.

Ketiga wujud kebudayaan tersebut saling berkaitan, demikian pula dengan kesenian. Lewat kesenian masyarakat mencoba mengungkapkan segala maksud dalam isi jiwanya. Dengan demikian kesenian benar-benar merupakan media komunikasi bagi pengikutnya. Pengertian komunikasi tidak hanya melalui bahasa lisan saja, akan tetapi juga terjalin lewat berbagai macam kegiatan berkesenian. Rumah budaya Sangtakasta selalu ramai dikunjungi warga setempat untuk berkesenian khususnya untuk bermain Reyog Kendhang.

Reyog Kendhang Sangtakasta dalam penyajiannya ditarikan oleh 6 penari atau berpasangan dengan membawa kendhang (gembluk) di dalam menari, yang sekaligus sebagai instrument pengiringnya. Hal ini juga dijelaskan dalam "Sejarah dan Babad Tulungagung”, yaitu :

Rejog dapat kita katakan merupakan bentuk tarian jang sangat sederhana, sebab si penari masingmasing membawa instrumen sendiri jang berupa gendang.... Tarian ini merupakan tarian jang bersumber pada tari-tarian kuno, hal ini dapat kita buktikan dari adanya relief jang terdapat di candi Prambanan, jang menggambarkan orang menari berdjadjar dengan menggunakan instrumen gendang pula.

Kesenian ini dapat dimainkan lebih dari enam orang penabuh kendhang, dengan catatan menggunakan kelipatan enam, yaitu 12 dan 18 pemain, disesuaikan kebutuhan pagelaran. Jika menggunakan formasi 12, maka setiap jenis gembluk ditabuh dua pemain. Demikian halnya jika menggunakan formasi 18, maka setiap jenis gembluk ditabuh tiga pemain. Setiap gembluk dimainkan atau ditabuh seorang pemain. Lebih lanjut dikatakan juga oleh Munardi, bahwa tarian ini melukiskan para prajurit yang sangat pandai memainkan gendang-gendangnya yang khas. Penari yang berada paling depan dianggap sebagai pimpinan atau pengemudi gerak yang harus diikuti oleh penari yang berada di belakang.

Hal ini, penari yang berada di belakang harus senantiasa tanggap atau peka terhadap segala perubahan atau perpindahan gerak maupun pola lantai yang telah diberi aba-aba oleh pemimpinnya. Di samping itu sebagai penari yang berada paling depan (pemimpin) harus dipilih penari yang cukup tangguh, kuat, dan kreatif terhadap jenis gerak maupun komposisinya, sehingga penari baik yang berada di depan maupun penari yang berada di belakang harus ada kerja sama yang baik di dalam pementasannya.

Gerak di dalam seni tari merupakan ekspresi jiwa manusia diungkapkan melalui gerak-gerak yang ritmis dan indah. Gerak diartikan sebagai kode, dengan makna-makna dibawakan dalam karakter musik yang digunakan untuk penyampaian hingga emosi bisa tersampaikan. Gerak yang teratur dan direncanakan sebelumnya akan menjadikan sebuah gerak baku. Akan tetapi, pengertian gerak adalah ketika seorang pemain yang menggerakan tubuhnya ketika menikmati musiknya. Ragam-ragam geraknya dominan pada gerak kaki, sedangkan badan dan kepala seringa digunakan hanya sebagai penyerta atau efek daripada gerak kaki pada waktu menari.

Sebagaimana diuraikan di atas, bahwa para penari juga penabuh instrumen yaitu membawa dan menabuh gmblug. Maka konsekuensinya gerak tarinya sangat terbatas pada gerakan kepala dan kaki. Oleh karena itu gerak tari Reyog Kendhang Tulungagung ini sangat terbatas. Sesuai dengan jumlah gemblugnya ada 6 buah, maka penarinya juga ada 6 orang penari, jumlah ini biasa disebut satu unit Reyog Kendhang Tulungagung.

Penampilan tari Reyog Kendhang ini dapat ditarikan dengan satu unit kelompok dengan 6 penari, 
dapat pula dalam bentuk tarian masal yang terdiri atas beberapa unit. Baik tarian satu unit ataupun beberapa unit para penari dapat mengadakan gerakan tidak monoton dalam barisan unitnya, melainkan dapat menggandakan gerakan dalam bentuk konfigurasi, atau gerak lantai. Gerak lantai ini tergantung improvisasi dari koreografinya. Namun disamping bebas dalam gerak lantai, maka perlu memperhatikan jenis-jenis gerakan tari yang tetap atau baku dengan bertumpu pada gerak kepala dan kaki. Dalam setiap pertunjukan Sangtakasta sering menampilkan gaya gerak bermusik yang interaktif. Adapun beberapa gerak Reyog Kendhang yaitu: gerak baris, gerak menthokan, gerak pattetan, gerak kejang, gerak lilingan, gerak ngongak sumur, gerak gejoh bumi, gerak midak kecik, gerak sundang, gerak andul, gerak gembyangan.

Secara umum kostum/pakaian pentas, bisa menjadi sarana untuk menampilkan pesan kepribadian, status sosial dan sebagainya. Kostum merupakan salah satu unsur lebih memperindah penampilan di atas panggung. Selain itu dengan adanya kostum, bisa lebih memperkuat unsur artistik agar para pemain terlihat berbeda dan lebih indah. Konstum yang digunakan Reyog Kendhang Sangtakasta pada dasarnya sama dengan kostum-kostum yang digunakan oleh kelompok-kelompok kesenian Reyog Kendhang yang lainnya. Adapun beberapa kostum Reyog Kendhang yaitu: udeng, guling, sumping, kacamata hitam, baju, celana pendek, kain panjang, stagen, sabuk, kace, ter, srempang, boro-boro, sampur, keris, deker, kaos kaki, dan gongsyeng atau klinthing.

Pertunjukan Reyog Kendhang terdiri dari beberapa bentuk penyajiannya salah satunya untuk rangkaian upacara dan untuk hiburan. Persiapan pertunjukan untuk hiburan atau tontonan tidak menggunakan sajen, tetapi untuk pertunjukan yang diselenggarakan dalam rangkaian upacara seperti misalnya khitanan dan perkawinan selalu menggunakan sajen. Sajen pada Reyog Kendhang merupakan perlengkapan yang penting sekali. Tidak hanya pada tari Reyog Kendhang saja yang menggunakan sajen, akan tetapi di setiap daerah tarian upacara selalu dilengkapi dengan sajen. Meskipun sajen itu di lain daerah lain pula jenis sajennya. Adapun sajen yang dibutuhkan terdiri dari :

1. Nasi buceng lengkap dengan lauk pauknya;

2. Ayam panggang utuh (ingkung);

3. Pisang raja setangkep (dua sisir);

4. Gula gimbal atau gula grinsing;

5. Bunga rampai atau bunga setaman;

6. Ayam hidup satu yang digantungkan pada tiang kempul.

Semua perlengkapan sajen itu apabila sudah siap kemudian diserahkan kepada pimpinan pertunjukan (gambuh) untuk diteliti kembali. Setelah semua persiapan lengkap pemimpin pertunjukkan (gambuh) menyalakan dupa pertanda dimulainya pertunjukan tari Reyog Kendhang. Pertunjukan dilakukan di halaman rumah atau di tanah lapang yang luas sebagaimana tari-tarian rakyat lainnya. Reyog
Kendhang juga digunakan sebagai pengarak ritual tahunan yang dilakukan pemerintah Kabupaten Tulungagung yaitu jamasan pusaka tombak Kyai Upas. Ritual ini dipercayai sebagi ritual tolak bala untuk keselamatan masyarakat Kabupaten Tulungagung dari berbagai bencana alam khususnya bencana banjir, karena pada jaman dahulu Kabupaten Tulungagung sering dilanda bencana banjir yang amat sangat mengerikan. Kegunaan fungsi musik, Alan P. Meriam mendefinisikan bahwa fungsi musik dalam konteks kebudayaan terbagi menjadi 10 kategori, yaitu: sebagai pengungkapan emosi, penghayat estetis, hiburan, komunikasi, perlambangan, reaksi fisik, yang berkaitan dengan norma-norma sosial, pengesahan lembaga sosial, upacara agama, fungsi kesinambungan budaya dan pengintegrasian masyarakat. Kesenian Reyog Kendhang di Desa Tugu mempunyai beragam fungsi, salah satunya sebagai sarana Upacara dan hiburan. Kehadiran seni pertunjukan di jaman modern, digunakan dalam dua hal, yaitu : sebagai sarana upacara dan hiburan.

Upacara yang sifatnya magis pasti akan menggunakan persembahan-persembahan sebagai ungkapan rasa syukur kepada Sang Maha Pencipta. Kegiatan ini biasanya dilakukan pada tempat-tempat yang memenuhi persyaratan tertentu dan alat-alat tertentu di antaranya alat bunyi-bunyian yang diharapkan sebagai pendukung suasana untuk berkomunikasi sakral, juga pakaian khusus yang digunakan supaya yang melakukan dapat khusyuk (konsentrasi). Reyog Kendhang sebagai sarana hiburan bersifat bebas tanpa sesaji-sesaji dan semata-mata hanya bersifat menghibur. Setiap malam pada hari-hari tertentu sanggar Sangtakasta ramai dikunjungi banyak orang, baik dari para pemain yang sedang berlatih dan para penonton yang datang untuk mencari sebuah hiburan. Sangtakasta tidak hanya mengisi acara di daerah Kecamatan Sendang saja, melainkan sampai keluar kota, seperti Surabaya, Malang, Samarinda bahkan sampai ke Danau Toba. Sangtakasta juga sering mendapatkan undangan untuk mengisi acara yang diselenggarakan oleh parpol tertentu dan lain sebagainya. Musik saat dimainkan dapat merangsang sel-sel saraf manusia sehingga menyebabkan tubuh bergerak mengikuti irama musik tersebut. Musik Reyog Kendhang sangat merangsang pendengar, kebanyakan yang mendengar terangsang dan ingin berjoged mengikuti alunan musik. Dilihat dari segi komunikasi, Reyog kendhang juga berperan sebagai sarana komunikasi. Komunikasi yang dilakukan antar pemain dan pemain terhadap pemusik tambahan yang mengiringi seperti kempul, kenong sangat penting untuk kesuksesan suatu pementasan seni pertunjukan , khususnya kesenian Reyog Kendhang ini. Reyog Kendhang Sangtakasta Selain sebagai sarana upacara, hiburan dan sarana-sarana lainya di atas, Reyog Kendhang Sangtakasta juga difungsikan sebagai pengesahan suatu lembaga sosial. Hal ini bisa dilihat dari betapa seringnya Sangtakasta diundang oleh lembaga-lembaga tertentu baik di lingkungan 
Kecamatan Sendang, bahkan sampai luar kota. Sebagai contoh, Sangtakasta pernah di undang oleh partai PAN (Partai Amanat Nasional) yang dulu diketuai oleh Hatta Radjasa untuk menjadi salah satu kesenian yang mengesahkan jalanya acara tersebut.

\section{PENUTUP}

Masyarakat dalam proses kehidupannya pasti akan mengalami perubahan. Perubahan sosial di dalam suatu masyarakat juga akan diikuti oleh perubahan budaya, hal ini dikarenakan masyarakat tidak bisa terlepas dari kebudayaanya. Begitu juga dengan kesenian Reyog Kendhang Tulungagung yang mengalami perubahan dari masa ke masa, baik dari segi musikal berupa pola permainan, penyajian, maupun dari segi fungsinya. Kreativitas baru merupakan bentuk pembaharuan dari sebuah seni tradisi, bahwasanya setiap generasi mempunyai masanya masing-masing. Bentuk musikal dari kesenian Reyog Kendhang banyak mengalami perubahan, baik dari pola permainan gembluknya , balunganya dan instrument-instrumen lain yang menjadi instrument tambahanya di pertunjukan kesenian Reyog Kendhang Sangtakasta. Peran dan fungsi Reyog Kendhang Sangtakasta terhadap masyarakatnya khususnya desa Tugu dan Kabupaten Tulungagung pada umumnya sangatlah penting, karena melalui Sangtakasta kearifan lokal daerah setempat khususnya Desa Tugu dan Kabupaten Tulungagung bias terjaga dan terlestarikan walaupun dengan skala kecil, fungsi Reyog Kendhang yang dahulu digunakan sebagai sarana ritual sekarang juga bisa digunakan sebagai sarana hiburan dan lain sebagainya. Perkembangannya yang pesat sedikit banyak juga membantu masyarakat Kabupaten Tulungagung khususnya dibidang ekonomi kreatif. Sangtakasta merupakan salah satu sanggar seni yang melakukan sebuah pembaharuan itu. Sebuah karya seni akan selalu berkembang mengikuti perkembangan jaman termasuk dengan kesenian Reyog Kendhang. Generasi muda saat ini sangat mempengaruhi dan banyak berperan dalam mati atau hidupnya sebuah seni tradisional. Lebih baik sebuah seni tradisional yang sudah ada dikemas sedemikian rupa dengan kreativitas baru tetapi tidak meninggalkan pola bakunya atau keaslian daripada kesenian itu sendiri, sehingga eksistensinya tetap terjaga daripada dibiarkan hilang dan mati begitu saja karena tidak adanya sebuah pembaharuan.

Perlu adanya kesadaran dari intansi pemerintah terkait, untuk ikut berpartipasi dalam menjaga dan melestarikan kesenian-kesenian Kabupaten Tulungagung, sehingga proses yang telah dijalankan kelompok Sangtakasta bisa berlanjutan untuk masa yang akan datang dan juga perlu studi-studi terhadap fenomena musik Indonesia, sebagai pendokumentasian momen budaya yang hadir di masa kini. Dalam mengembangkan musik tradisional dan untuk melestarikan nilai-nilai budaya khusunya kesenian Reyog Kendhang bagi generasi muda terutama siswa- siswi SD, SMP, SMA dan SMK yang masih minim serta asing terhadap kesenian tradisional perlu diadakannya sebuah pergelaran musik tradisional di sekolah-sekolah.

\section{DAFTAR PUSTAKA}

Abdullah, Irwan. 2007. Konstruksi dan Reproduksi Kebudayaan. Yogyakarta: Pustaka Pelajar.

Hadi, Sumandiyo. 2007. Sosiologi Tari. Yogyakarta: Pustaka.

Hartono. 1980. Reyog Ponorogo. Jakarta: Proyek Penulisan dan Penerbitan Buku Majalah Pengetahuan Umum dan Profesi Depdikbud.

Koentjaraningrat. 1981. Pengantar Ilmu Antropologi. Jakarta: PN Aksara Baru.

Koentjaraningrat. 1984. Kebudayaan Jawa. Jakarta: Balai Pustaka.

Koentjaraningrat. 1985. Ritus Peralihan di Indonesia. Jakarta: PN. Balai Pustaka.

Merriam, P Alan 1964. The Anthropology of Music. Evanston Illinois: Northwestern University Press.

Moleong, J Lexy. 2013. Metodologi Penelitian Kualitatif. Bandung: PT Remaja Rosdakarya.

Munardi, A.M. 1978. Pengetahuan Tari Jilid 1. Surabaya: Sekolah Menengah Karawitan Indonesia.

Nakagawa, Shin. 2000. Musik dan Kosmos: Sebuah Pengantar Etnomusikologi. Jakarta: Yayasan Obor Indonesia

Netll, Bruno. 1964. Theory and Method Ethnomusicology. London: The free Press of Glencoe Collier Macmilan Limited.

Sedyawati, Edi. 1980. Pertumbuhan Seni Pertunjukan. Jakarta: Sinar Harapan.

Soedarsono, RM. 1984. Wayang Wong the State Ritual Dance Drama in the Court of Yogyakarta. Yogyakarta: Gajah Mada University Press.

Soedarsono, RM. 2010. Seni Pertunjukan Indonesia di Era Globalisasi. Yogyakarta: Gajah Mada University Press.

Soedarsono, RM. 1976. Tari-tarian Rakyat di Daerah Istimewa Yogyakarta. Yogyakarta: Gajah Mada University Press.

Soedarsono, RM.1975. Komposisi Tari Elemen-elemen Dasar. Yogyakarta: Akademi Seni Tari Indonesia Yogyakarta.

Soedarsono, RM. 1976. Djawa dan Bali. Yogyakarta: Gajah Mada University Press.

Supanggah. Rahayu. 2002. Bothekan Karawitan 1. Jakarta: Masyarakan Seni Pertunjukan Indonesia.

Shadily, Hassan. 1989. Sosiologi untuk masyarakat di Indonesia. Jakarta: Bina Akasara. 
Timoer, Soenarto. 1979. Reog di Jawa Timur. Surabaya: Departemen Pendidikan dan Kebudayaan Direktorat Jenderal Kebudayaan.

Sari. Titi. Tari Reyog Kendhang Tulungagung : Satu Tinjauan Sosio-Budaya. Skripsi S-1 jurusan Tari, Fakultas Seni Pertunjukan, Institut Seni Indonesia Yogyakarta. 1990.
Muljono. Untung. Sepintas Tari Rakyat Reyog Dari Kabupaten Tulungagung Jawa Timur. Laporan Tugas Akhir untuk mencapai derajat Ahli Madya pada Studi Tari, Akademi Seni Tari Yogyakarta. 1981. 